\title{
Analysis of the business pattern and tuna fishing season in the Southeast Minahasa Regency, North Sulawesi Province
}

\author{
Analisis pola usaha dan musim penangkapan ikan tuna di Kabupaten Minahasa \\ Tenggara, Provinsi Sulawesi Utara
}

\author{
Dedy Suprianto $^{1 *}$, Jhonny Budiman ${ }^{2}$, and Heffry V. Dien ${ }^{2}$ \\ ${ }^{1}$ Program Studi Magister Ilmu Perairan, Program Pascasarjana Universitas Sam Ratulangi. \\ Jln. Kampus Unsrat Kleak, Manado 95115, Sulawesi Utara, Indonesia. \\ ${ }^{2}$ Fakultas Perikanan dan Ilmu Kelautan, Universitas Sam Ratulangi. Jl. Kampus Unsrat Bahu, \\ Manado 95115, Sulawesi Utara, Indonesia. \\ *E-mail: dedysuprianto03@gmail.com
}

\begin{abstract}
This study was aimed to analyze the condition of the tuna fishery business pattern practiced by tuna fishermen and analyze the effort and the exploitation rate for fishing season determination. Data collection was done in Belang District, Southeast Minahasa Regency, for 5 months. The study was descriptive using primary and secondary data. Business pattern was determned using the interactive models of analysis and fishing season applied Average Percentage Methods based on Time Series Analysis. Results showed that fishermen in Southeast Minahasa Regency used the fishing boat owner to bear the operational cost under low selling. Tuna fishing season in Maluccas Sea, based on catches landed in the fishing port of Belang, occurred October to January and May to March because of good weather condition and high fish stock availability in the raft, while famine season occurred in in June to September because of bad weather, difficulty to operate the gear and low tuna stock. As a conclusion, in the famine season the fishermen in Southeast Minahasa Regency applied operational costs borne by the boat owner, but in the fishing season, it became a shared cost through revenue sharing. Tuna fishing season occurred in October to January.
\end{abstract}

Keywords: tuna; hand line fishing; Average Percentage Method.

Abstrak: Penelitian ini bertujuan untuk menganalisis kondisi perikanan tuna guna mengetahui pola usaha yang dijalankan oleh nelayan tuna dan menganalisis upaya penangkapan serta tingkat pemanfaatan guna mengetahui musim penangkapan ikan tuna. Pengambilan data dilakukan di Kecamatan Belang, Kabupaten Minahasa Tenggara, selama 5 (lima) bulan, Penelitian ini bersifat deskriptif, dengan penggunaan data primer dan sekunder. Selanjutnya data tersebut di analisis untuk mengetahui pola usaha nelayan tuna dengan menggunakan motode interactive model of analysis, sedangkan pola musim penangkapan ikan dianalisis menggunakan Metode Persentase Rata-rata yang didasarkan pada Analisis Runtun Waktu. Hasil penelitian ini menunjukkan bahwa nelayan Kabupaten Minahasa Tenggara menggunakan pola usaha dengan sistem pembiayaan ditanggung oleh pemilik dengan harga jual ikan rendah kepada pemilik perahu. Musim penangkapan ikan tuna di laut Maluku berdasarkan hasil tangkapan yang didaratkan di pelabuhan perikanan belang terjadi pada bulan Oktober sampai Januari dan Mei sampai Maret ini karena cuaca lebih baik dan ketersediaan ikan banyak di rakit, sedangkan musim pecaklik terjadi pada bulan Juni hingga September karena cuaca yang buruk, kesulitan untuk mengoperasikan alat tangkap, serta kurangnya ikan tuna di rakit. Sebagai kesimpulan, nelayan Kabupaten Minahasa Tenggara menggunakan pola usaha dengan sistem biaya operasional menjadi beban pemilik disaat musim peceklik, sedangkan pada musim ikan pola pembagian hasil dijalankan dengan biaya operasional menjadi beban bersama. Musim penangkapan ikan tuna terjadi pada bulan Oktober sampai Januari.

Kata-kata kunci: tuna; penangkapan ikan hand line; Metode Persentase Rerata.

\section{PENDAHULUAN}

Indonesia mempunyai sumber daya ikan yang berpotensi dari segi jumlah dan jenisnya. Salah satu sumber hayati laut di Indonesia adalah perikanan tuna yang memiliki nilai ekonomis cukup tinggi sehingga tuna dapat dijadikan salah satu andalan ekspor non migas dari sektor perikanan. Potensi perikanan tuna di Indonesia menurut Komisi Nasional Pengkajian Stok cukup besar sedangkan beberapa daerah tertentu tingkat pemanfaatannya masih rendah. Meskipun tingkat pemanfaatan ikan 
tuna di Indonesia sampai saat ini dapat dikatakan masih di bawah Total Allowable Catch (TAC) atau jumlah tangkapan yang diperbolehkan, namun pengelolaan sejak dini sangat dibutuhkan mengingat sifat dari ikan tuna tergolong peruaya jarak jauh (Luasunaung, 2006).

Perairan laut Kabupaten Minahasa Tenggara merupakan salah satu kawasan Wilayah Pengelolaan Perikanan Negara Republik Indonesia (WPPNRI) 715 yang memiliki sumberdaya perikanan yang potensial, seperti ikan tuna mata besar (bigeye tuna), madidihang (yellowfin tuna) dan cakalang (skipjack tuna). Alat tangkap yang umum digunakan nelayan untuk memanfaatkan sumberdaya tersebut adalah pancing hand line yang berpangkalan di Pelabuhan Perikanan Belang.

Tulisan ini membahas mengenai periode musim penangkapan ikan tuna di perairan Laut Maluku, berdasarkan hasil tangkapan dan jumlah trip penangkapan per bulan dengan alat tangkap tuna hand line. Lokasi pengambilan data yaitu di Pelabuhan Perikanan Belang selang waktu 20112015.

\section{MATERIAL DAN METODA}

Analisis data untuk mengetahui pola usaha yang dijalankan oleh nelayan tuna di Kabupaten Minahasa Tenggara digunakan interactive model of analysis menurut Miles dan Hubberman 1992, Analisis model interaktif ini melalui 4 tahap yaitu pengumpulan data, reduksi data, penyajian data dan penarikan kesimpulan / verifikasi.

Analisis pola musim penangkapan ikan menggunakan Metode Persentase Rata-rata (The Average Percentage Methods) yang didasarkan pada Analisis Runtun Waktu (Times Series Analysis) (Spiegal M.R, 1961 dalam Kakenusa, 2006), Prosedurnya ialah sebagai berikut :

a. Hitung nilai hasil tangkapan per upaya tangkap $($ CPUE $=$ Catch Per Unit of Effort $=U)$ per bulan $\left(\mathrm{U}_{\mathrm{i}}\right)$ dan rata-rata bulanan CPUE dalam setahun $(\bar{U})$.

$$
\bar{U}=\frac{1}{m} \sum_{i=1}^{m} U_{i}
$$

$$
\begin{aligned}
& \bar{U}=\underset{\text { CPUE rata-rata bulanan dalam setahun }}{\text { (ton/trip) }} \\
& U_{i}=\text { CPUE per bulan (ton/trip) } \\
& \mathrm{m}=12 \text { (jumlah bulan dalam setahun) }
\end{aligned}
$$

b. Hitung $U_{p}$ yaitu rasio $U_{i}$ terhadap $\bar{U}$ dinyatakan dalam persen :

$$
U_{p}=\frac{U_{i}}{\bar{U}} \times 100 \% \ldots \ldots \ldots \ldots \ldots \ldots \ldots
$$

c. Selanjutnya dihitung:

$$
\begin{aligned}
I M_{i} & =\frac{1}{t} \sum_{i=1}^{t} U_{p} \ldots \ldots \ldots \ldots \ldots \ldots \ldots \ldots \\
\mathrm{IM}_{\mathrm{i}} & =\text { Indeks Musim ke } \mathrm{i} \\
\mathrm{t} & =\text { Jumlah tahun dari data }
\end{aligned}
$$

d. Jika jumlah $\mathrm{IM}_{\mathrm{i}}$ tidak $1200 \%$ (12 bulan x 100 $\%$ ), maka diperlukan penyesuaian dengan rumus (3) sebagai berikut :

$$
\begin{aligned}
I M S_{i} & =\frac{1200}{\sum_{i=1}^{m} I M_{i}} \times \operatorname{IM}_{\mathrm{i}} \ldots \ldots \ldots \ldots \ldots \ldots \text { (4) } \\
\mathrm{IMS}_{\mathrm{i}} & =\text { Indeks Musim ke i yang disesuaikan }
\end{aligned}
$$

e. Jika dalam perhitungan ada nilai ekstrim pada $\mathrm{U}_{\mathrm{p}}$, maka nilai $\mathrm{U}_{\mathrm{p}}$ tidak digunakan dalam perhitungan Indeks Musim (IM), yang digunakan ialah median (Md) dari IM tersebut. Jika jumlah nilai Md tidak sebesar $1200 \%$, maka perlu dilakukan penyesuaian sebagai berikut :

$$
\begin{aligned}
I M M d S_{i} & =\frac{1200}{\sum_{i=1}^{m} M d_{i}} \times \operatorname{Md}_{\mathrm{i}} \ldots \ldots \ldots \ldots . . . .(5) \\
\mathrm{IMMdS}_{\mathrm{i}}= & \begin{array}{c}
\text { Indeks Musim dengan Median } \\
\text { yang disesuaikan ke } \mathrm{i} .
\end{array}
\end{aligned}
$$

Kriteria penentuan musim ikan ialah jika indeks musim lebih dari 1 (lebih dari $100 \%$ ) atau di atas rata-rata, dan bukan musim jika indeks musim kurang dari 1 (kurang dari $100 \%$ ). Apabila IM $=1$ (100\%), nilai ini sama dengan harga rata-rata bulanan sehingga dapat dikatakan dalam keadaan normal atau berimbang.

\section{HASIL DAN PEMBAHASAN}

Unit Penangkapan hand line oleh nelayan setempat memiliki bagian-bagian konstruksi umum yang terdiri sejumlah tali (line), gulungan dan mata pancing (hock), tali terbuat dari benang nylon, gulungan terbuat dari kayu atau gabus sedangkan 
mata pancing biasanya terbuat dari stainless atau kawat baja, ini dimaksud agar mata pancing tidak mudah berkarat dan kuat.

Alat bantu penangkapan berupa rumpon merupakan tempat berteduh dan mencari makan bagi ikan-ikan pelagis karena itu rumpon ini dipasang di laut yang relatif dalam. Pemasangan rumpon dimaksudkan untuk menarik gerombolan ikan agar berkumpul di sekitar rumpon sehingga ketersediaan makanan bagi ikan predator seperti tuna menjadi ada, sehingga dalam kegiatan proses penangkapan menjadi lebih efektif dan efisien karena tidak lagi berburu ikan (dengan mengikuti alur ruayanya), tetapi cukup melakukan kegiatan penangkapan di sekitar rumpon, konstruksi rumpon yang digunakan sebagai alat bantu penangkapan tergolong sederhana yang terdiri dari pengapung, tali jangkar, jangkar atau pemberat, antraktor (pemikat ikan), rumah jaga dan tiang penanda.

Sebelum melakukan kegiatan operasi penangkapan perlu dilakukan hal-hal sebagai berikut:

a. persiapan kapal yang merupakan salah satu sarana yang mutlak dalam operasi penangkapan ikan dalam hal ini merupakan satuan yang kompleks, karena apabila suatu sistem tidak berfungsi, maka akan mengakibatkan kegiatan penangkapan terhambat, persiapan kapal meliputi:

1) Persiapan bahan bakar, dalam setiap trip digunakan solar sebanyak 600 liter sampai 1000 liter, penentuan jumlah tersebut berdasarkan sisa bahan bakar yang tersedia di kapal, setelah kegitan melaut hal ini didasarkan pada jauhnya fishing ground yang akan dituju.

2) Persiapan mesin, meliputi pemeriksaan minyak pelumas, sistem pendinginan dan bagian-bagian penting lainnya agar daya kerja mesin terpelihara dengan baik dan optimal.

b. Persiapan tenaga kerja

Untuk kapal hand line yang berpangkalan di pelabuhan perikanan Belang pada umumnya menggunakan 5 sampai 8 orang yang terdiri dari 1 orang kapten, 1 orang masinis, 1 orang kepala serang dan sisanya anak buah kapal (ABK).

c. Persiapan perbekalan

Dalam suatu operasi penangkapan dengan hand line yang didaratkan di pelabuhan perikanan Belang membutuhkan waktu 2 (dua) hari dalam penyiapan perbekalan yang meliputi: pemuatan es batu yang sudah digiling, pemuatan air tawar, pemuatan bahan bakar dan bahan makanan.

Operasi penangkapan memerlukan lama melaut antara $7-14$ hari. Lama melaut ditentukan berdasarkan jumlah es yang dibawa dan keberadaan ikan. Faktor es menjadi penting karena sifat ikan tuna mudah rusak yang akan menentukan harga jual. Berdasarkan sifatnya ikan tuna dapat melakukan migrasi jarak jauh (migratory species) dari samudera pasifik ke samudera Hindia dan sebaliknya, hal tersebut menyebabkan pola penangkapan ikan tuna di Minahasa Tenggara dibedakan menjadi tiga musim penangkapan yaitu musim puncak, peralihan, dan paceklik. Biaya tidak tetap (variable cost) yang dikeluarkan terdiri dari biaya operasional penangkapan dan biaya perbekalan/ransum. Biaya operasional terbesar yang dikeluarkan adalah biaya bahan bakar minyak dan biaya es. Dalam satu kali trip penangkapan, armada penangkapan membutuhkan bahan bakar minyak sebanyak 600 - 1.000 liter dan es balok sebanyak 80 - 100 balok es.

Investasi yang dibutuhkan untuk usaha penangkapan tuna di Minahasa Tenggara pada ukuran kapal $>5$ GT adalah sebesar 70 - 200 jutaan. Sebagian besar kapal yang digunakan bermesin dalam dengan kemampuan mesin berkisar antara 4 - 6 Silinder yang disesuaikan dengan ukuran kapal. Pengoperasian penangkapan dilakukan dengan menggunakan pancing yang diberi umpan (Hand line) di mana satu unit armada penangkapan membutuhkan 15 - 30 alat pancing. Satu unit alat pancing lengkap membutuhkan biaya sekitar Rp. 250.000 - Rp. 300.000. Ukuran ikan tuna yang tertangkap dengan pancing sangat bervariasi, dari yang kecil sampai besar (lebih dari $60 \mathrm{~kg}$ / ekor).

Sistem pembagian hasil ini perlu disepakati bersama antara ABK selaku nelayan yang akan melakukan proses penangkapan ikan tuna dan pemilik kapal agar tidak terjadi kesalah pahaman dalam pembagian hasil tangkapan yang didapat, pada umumnya sistem yang diterapkan hanya untuk ikan target saja yaitu ikan tuna yang memiliki berat $>30 \mathrm{~kg}$, sedangkan untuk ikan lain yang tertangkap seperti cakalang, tongkol, dll, biasanya dibahas saat pembagian hasil tangkapan berlangsung, Namun jika ikan di luar target yang banyak tertangkap biasanya sebelum melakukan kegiatan pelayaran berikutnya perlu adanya kesepakatan baru kembali, semua ini tergantung dari musim ikan yang tersedia.

Di Minahasa Tenggara dikenal 2 pola pembagian hasil untuk penangkapan tuna hand line yaitu: 
a. Biaya operasional menjadi beban pemilik dan ABK (harga rendah)

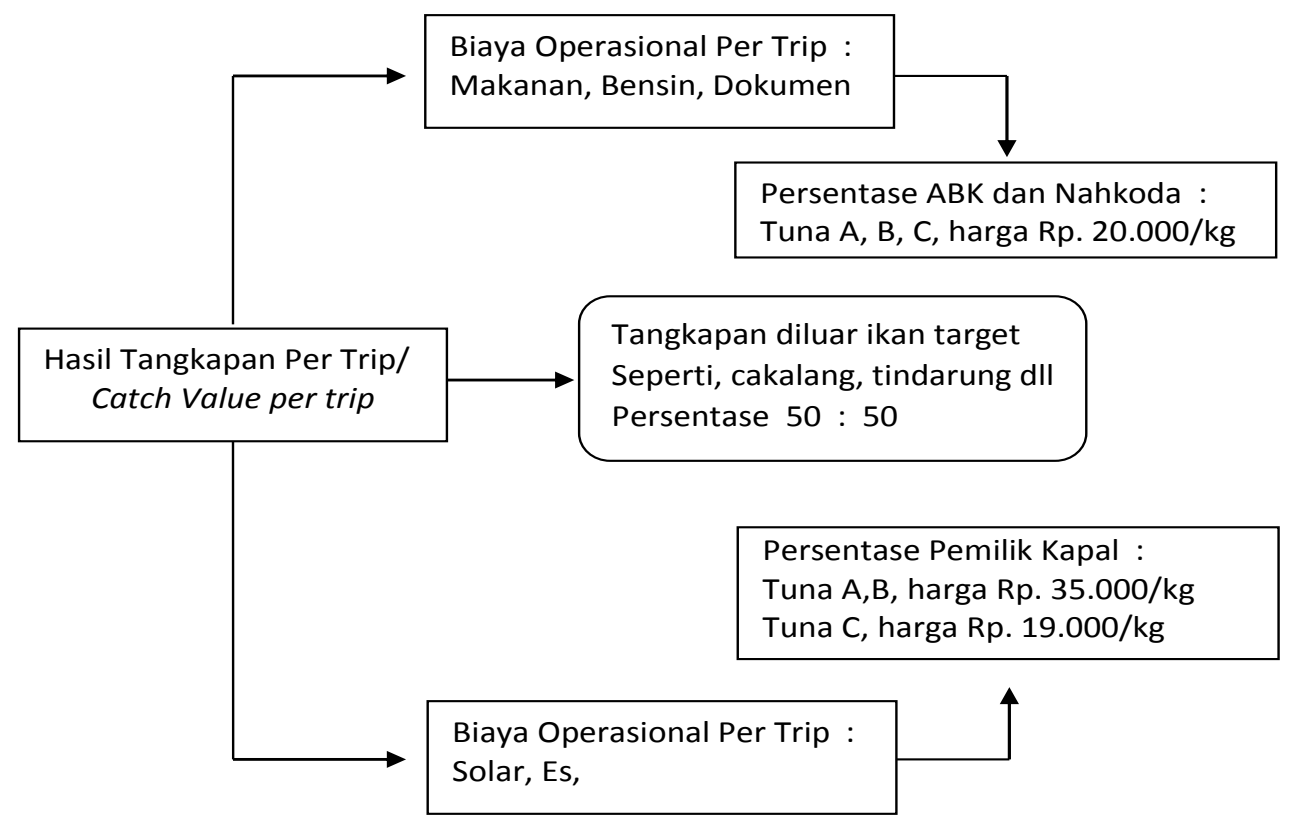

b. Biaya operasional menjadi beban ABK (harga tinggi)

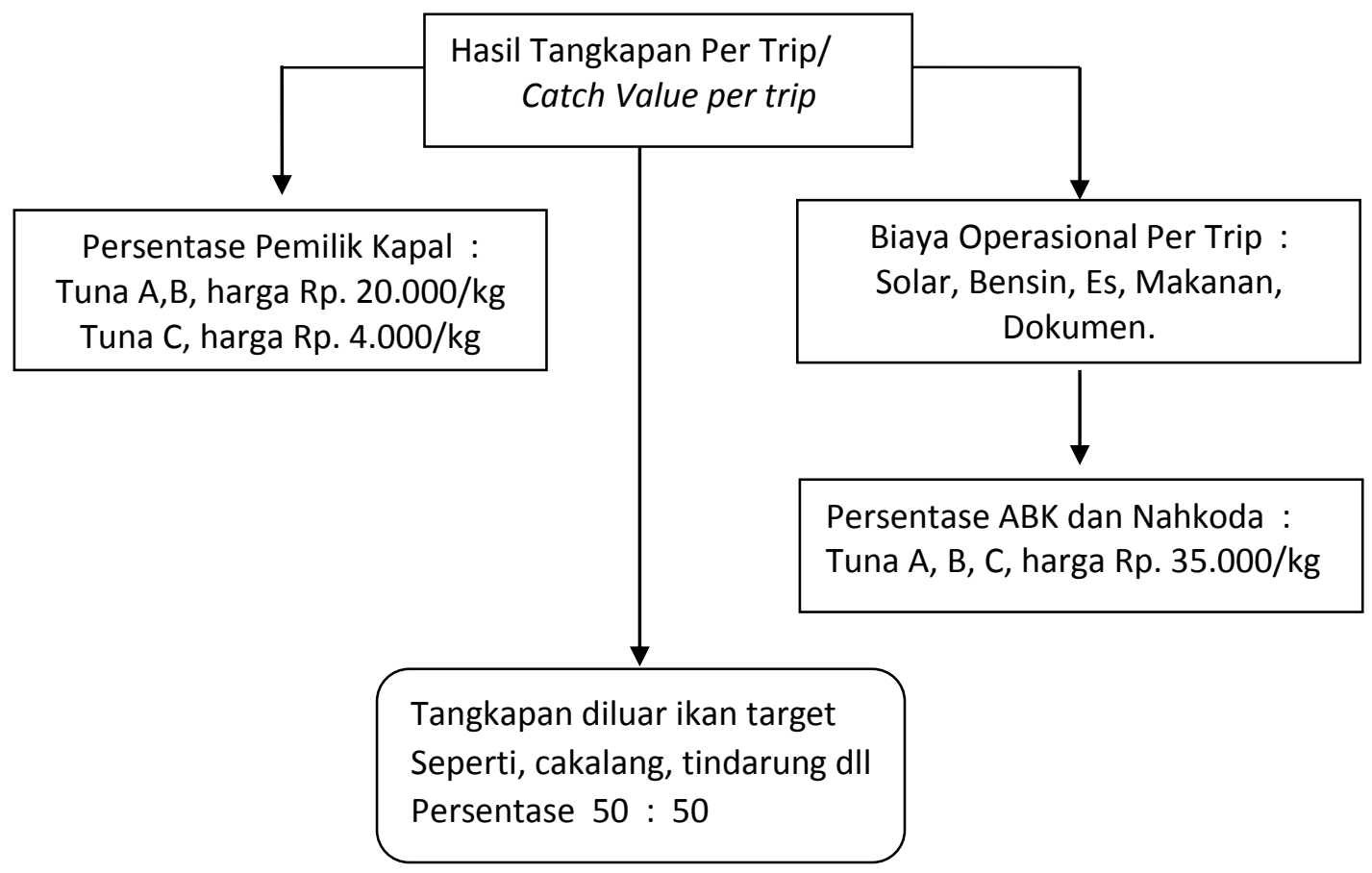

Untuk pola pembagian yang ini dengan ketentuan semua operasional dalam melakukan kegiatan pelayaran dibebankan kepada ABK tetapi harga jual ikan tuna lebih mahal dibandingkan dengan sistem pertama tapi $\mathrm{ABK}$ memiliki risiko ketika hasil tangkapan sedikit dan tidak mencukupi biaya operasional maka biaya operasional akan ditutupi dari hasil tangkapan berikutnya.
Data hasil tangkapan hand line yang di daratkan di pelabuhan perikanan belang Kabupaten Minahasa Tenggara pada tahun 2011 sampai dengan tahun 2015 disajikan pada tabel 1.

Dalam kurun waktu lima tahun (2011 sampai 2015) sebagaimana yang ditunjukkan pada tabel di atas, terlihat bahwa pada bulan - bulan tertentu untuk setiap tahunnya jumlah hasil tangkapan terbanyak pada bulan Oktober pada 2011, November pada 2012, November pada 2013, 
Suprianto et al.: Analysis of the business pattern and tuna fishing season in the Southeast...

Tabel 1. Hasil tangkapan hand line yang di daratkan di Pelabuhan Perikanan Belang Kabupaten Minahasa Tenggara dalam kurun waktu 2011 - 2015

\begin{tabular}{|c|c|c|c|c|c|c|c|}
\hline \multirow{2}{*}{ Bulan } & \multicolumn{5}{|c|}{ Tahun } & \multirow{2}{*}{ Jumlah } & \multirow{2}{*}{$\begin{array}{l}\text { Rata-rata } \\
\quad(\mathrm{Kg})\end{array}$} \\
\hline & 2011 & 2012 & 2013 & 2014 & 2015 & & \\
\hline Januari & 10500 & 18202 & 11786 & 13862 & 31205 & 85555 & 17111 \\
\hline Februari & 2600 & 10505 & 5532 & 14389 & 14762 & 47788 & 9557.6 \\
\hline Maret & 7609 & 8695 & 20641 & 16183 & 18258 & 71386 & 14277.2 \\
\hline April & 6189 & 5292 & 13735 & 14216 & 30719 & 70151 & 14030.2 \\
\hline Mei & 6781 & 12464 & 16565 & 13747 & 24962 & 74519 & 14903.8 \\
\hline Juni & 5623 & 7101 & 14767 & 18021 & 17618 & 63130 & 12626 \\
\hline Juli & 5442 & 2354 & 21295 & 15886 & 21507 & 66484 & 13296.8 \\
\hline Agustus & 7980 & 6449 & 8592 & 10690 & 3264 & 36975 & 7395 \\
\hline September & 9253 & 10356 & 9136 & 18723 & 1670 & 49138 & 9827.6 \\
\hline Oktober & 12313 & 12380 & 18639 & 11374 & 11373 & 66079 & 13215.8 \\
\hline November & 0 & 28745 & 24181 & 9775 & 14719 & 77420 & 15484 \\
\hline Desember & 9819 & 26561 & 16021 & 5597 & 15390 & 73388 & 14677.6 \\
\hline Total & 84109 & 149104 & 180890 & 162463 & 205447 & 782013 & \\
\hline Rata-rata & 7009.083 & 12425.33 & 15074.17 & 13538.58 & 17120.58 & 65167.75 & \\
\hline
\end{tabular}

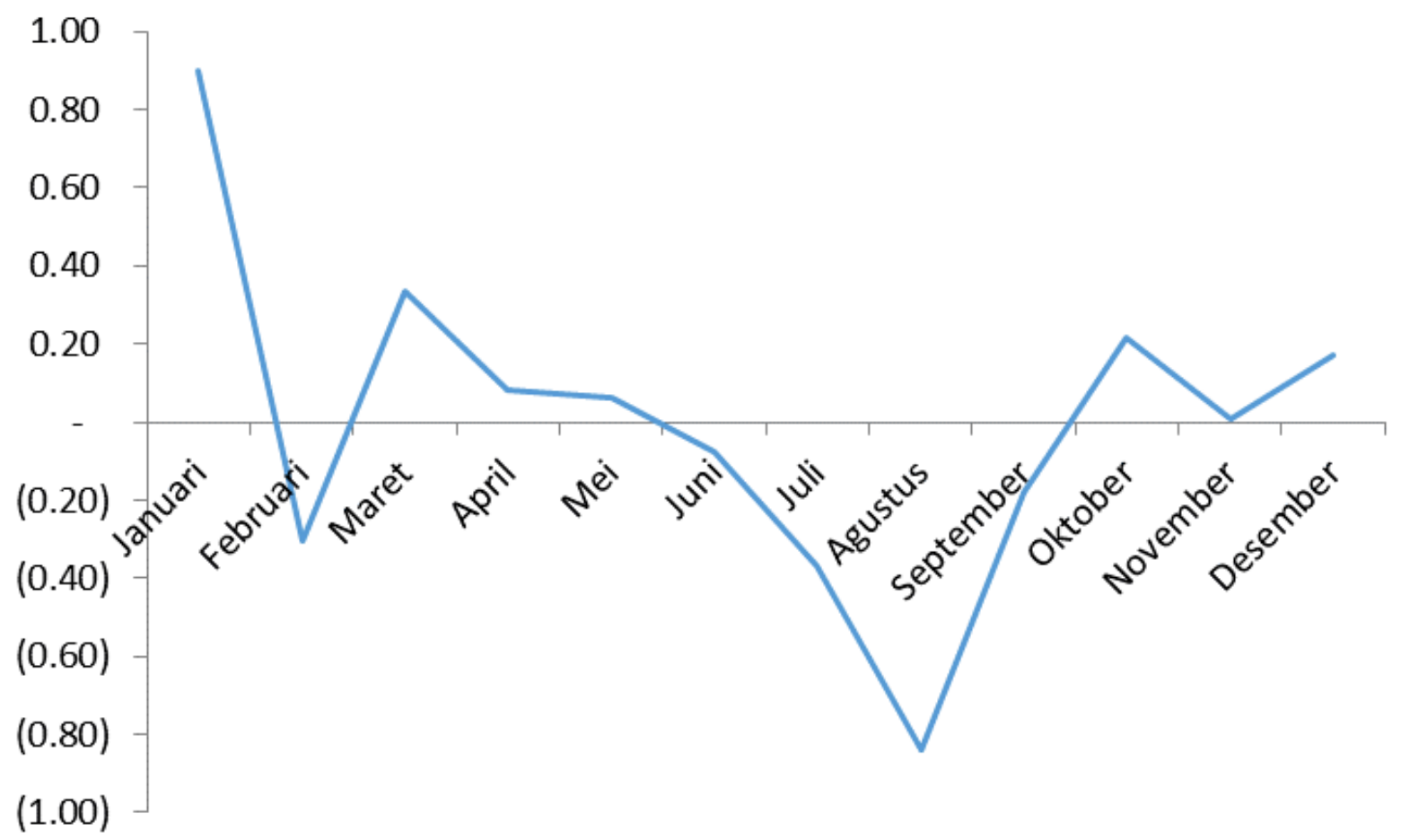

Gambar 1. Pola musim penangkapan ikan tuna di Kabupaten Minahasa Tenggara tahun 2011 sampai 2015 
September pada 2014 dan pada tahun 2015 hasil terbanyak pada bulan Januari. Sedangkan hasil terendah pada bulan November 2011 ini terjadi karena pada saat ini cuaca buruk dan mengakibatkan semua kapal nelayan tidak melakukan aktivitas melaut.

Berdasarkan grafik pola musim ikan di atas terlihat bahwa musim penangkapan ikan tuna pada perairan laut Maluku dan sekitarnya berdasarkan hasil tangkapan yang didaratkan di Pelabuhan Perikanan Belang, Kabupaten Minahasa Tenggara, terjadi pada bulan Oktober sampai Januari dan Maret sampai Mei, indeks musim tertinggi terjadi pada bulan Januari, hal ini terjadi karena pengaruh cuaca yang baik dan ketersediaan ikan di rakit sehingga para nelayan dapat melakukan aktivitas penangkapan ikan dengan leluasa dan baik, sedangkan pada bulan Juni hingga September adalah musim paceklik hal ini karena cuaca kurang baik yang mengakibatkan sulitnya untuk mengoperasikan alat tangkap sehingga penghasilan para nelayan menjadi berkurang.

Untuk musim puncak artinya dengan adanya ketersediaan ikan tuna di rakit dan cuaca baik maka berdasarkan kuesioner yang diambil dapat disimpulkan bahwa nelayan lebih cenderung menggunakan sistem pembagian hasil dengan pola kedua yaitu harga jual ikan tuna lebih tinggi dengan konsekuensi biaya operasional seperti : minyak solar, minyak bensin, es, dan makanan menjadi beban bersama antara pemilik dan nelayan (ABK), namun jika datang masa paceklik maka kecenderungan masyarakat nelayan akan menggunakan pola pembagian hasil yang pertama yaitu biaya operasional untuk minyak solar dan es menjadi beban pemilik sedangkan biaya makanan dan minyak bensin menjadi beban nelayan (ABK), hal ini bertujuan untuk mengurangi risiko kerugian baik antara pemilik dan nelayan (ABK), karena biasanya di saat musim paceklik datang maka ikan di luar target seperti cakalang, tongkol, dll. akan lebih banyak yang tertangkap sehingga dapat menutupi biaya operasional kapal.

\section{KESIMPULAN}

Berdasarkan hasil penelitian yang telah dilakukan, maka dapat disimpulkan sebagai berikut:

1. Masyarakat nelayan Kabupaten Minahasa Tenggara menggunakan pola usaha dengan sistem biaya operasional menjadi beban pemilik di saat musim paceklik tiba namun di saat musim tuna datang maka pola pembagian hasil yang dijalankan dengan biaya operasional menjadi beban bersama.

2. Musim penangkapan ikan tuna di perairan laut Maluku berdasarkan hasil tangkapan yang didaratkan di Pelabuhan Perikanan Belang terjadi pada bulan Oktober sampai Januari dan Maret sampai Mei, sedangkan pada bulan Juni hingga September adalah musim paceklik.

\section{REFERENSI}

ARIKUNTO, S. (1997) Prosedur Penelitian. Jakarta: PT. Rineka Cipta.

AYODHYA (1981) Metode Penangkapan Ikan. Bogor: Penerbit Yayasan Dewi Sri.

CHOLIQ, A.R, WIRASMITA and SOFWAN, O. (1999) Evaluasi Proyek (Suatu Pengantar). Bandung: Pionir Jaya. Hal 33-41.

DAHURI, R. (2001) Menggali Potensi Kelautan dan Perikanan dalam Rangka Pemulihan Ekonomi Menuju Bangsa yang Maju, Makmur dan Berkeadilan. Pidato dalam rangka Temu Akrab CIVA-FPIK-IPB tanggal 25 Agustus 2001. Bogor.

KAKENUSA, J.S. (2006) Analisis Penentuan musim penangkapan ikan Cakalang (Katsuwonus pelamis) di perairan sekitar bitung, Sulawesi Utara. Jurnal Protein, 13(1): $1-7$.

KEMENTERIAN KELAUTAN And PERIKANAN (2015) Rencana Pengelolaan Perikanan Tuna, Cakalang dan Tongkol.

LUASUNAUNG, A. (2006) Peranan suhu sebagai salah satu faktor penentuan daerah penangkapan ikan tuna. Makalah. Manado: Fakultas Perikanan dan Ilmu Kelautan, Universitas Sam Ratulangi.

MANTJORO, E. (1996) Ilmu Ekonomi Bisnis Kelautan. Laboratorium Ekonomi dan Bisnis Perikanan, Fakultas Perikanan Universitas Sam Ratulangi. Seri Dokumentasi dan Publikasi Ilmiah, Dharma Pendidikan.

MARCILLE, J., BOELY, T., UNAR, M., MERTA, G.S., SADHOTOMO, B. and UKTOLSEJA, J.C.B. (1984) Tuna Fishing In Indonesia. Editions de I'ORSTOM.

MILES, B.M. and HUBERMAN, A.M. (1992) Analisis Data Kualitatif. Jakarta: Universitas Indonesia Press.

MONINTJA, D. (1986) Beberapa Pembahasan Dalam Pole and Line Fishing di Aertembaga. Laporan Praktek (tidak diterbitkan). Mata Ajaran Pokok Teknik Penangkapan. Bogor: Fakultas Perikanan, Institut Pertanian Bogor. 
Suprianto et al.: Analysis of the business pattern and tuna fishing season in the Southeast...

NONTJI, A. (1987) Laut Nusantara. Jakarta: Penerbit Djambatan.

PANE, A.B. (1979) Manajemen Usaha Perikanan (Suatu Studi Pendahuluan pada Perikana Purse Seine). Karya Ilmiah Fakultas Perikanan. Bogor: Institut Pertanian Bogor.

SAANIN, H. (1984) Taksonomi dan Kunci Identifikasi Ikan. Jakarta: Bina Cipta.

SUBANI, W. and BARUS, H.R. (1989) Alat Penangkapan Ikan dan Udang Laut di Indonesia. Jakarta: Balai Penelitian Perikanan Laut.

SYAFRIN, N. (1993) Analisis Faktor-faktor yang mempengaruhi Pendapatan Usaha Penangkapan Ikan. (tidak dipublikasikan). Bogor: Sekolah Pasca Sarjana Institut Pertanian Bogor.
THOMSON (1978) Agriculture Marketing. New York, Toronto. London.

UNDANG-UNDANG REPUBLIK INDONESIA Nomor: 45 Tahun 2009, tentang Perubahan Undang Republik Indonesia Nomor: 31 Tahun 2004 tentang Perikanan. Jakarta.

UKTOLSEJA, J.C.B. (1987) Estimated Growth Parameters and Migration of Skipjack TunaKatsuwonus pelamis in the Eastern Indonesian Water Through Tagging Experiment. Jurnal Penelitian Perikanan Laut, 43: 15-44.

Received: 1 July 2017 Accepted: 5 August 2017 